gue un obiettivo trascendente. Io non lo faccio perché otterrò questo o quel beneficio, ma il fatto stesso di dedicarmi ad esso conferisce dignità alla mia esistenza" (p. 165).

Molto interessante la definizione dell'arte della domanda e dell'ascolto e di come imparare a domandare e ad ascoltare, una pratica tanto infrequente oggi.

E nella parte finale del libro è quanto meno interessante, se non imprescindibile, l'approfondimento di quello che gli autori definiscono gli ostacoli al dialogo, la cui lettura apre gli occhi su una nuovissima dimensione del dialogo.

Non è facile chiudere questa recensione perché ci sarebbero ancora parecchie sfumature da sottolineare, ma lasciamo che siano i lettori stessi a scoprirle, nella speranza di averli entusiasmati a iniziare insieme agli autori l'avventura di un "dialogo per la vita".

Araceli Del Pozo Armentia* ORCID: 0000-0002-0088-5609

Madrid, España

\title{
Silvina Chemen, Francisco Canzani, Un dialogo para la vida \\ [Dialog życia], Madrid: Editorial Ciudad Nueva, 2017, s. 236 [Buenos Aires: Editorial Ciudad Nueva, 2013; A dialogue of life, New York: JTS-New City Press, 2015]
}

DOI: http://dx.doi.org/10.12775/PCh.2019.038

Książka wydana w języku hiszpańskim przez argentyńskie wydawnictwo Ciudad Nueva w 2013, a potem w 2017 r. przez to samo wydawnictwo w Hiszpanii już samym tytułem Dialog życia (Un dialogo para la vida) zachęca do lektury. Podtytuł Ku spotkaniu żydów i chrześcijan wskazuje na podjęte w niej zagadnienia, przy nazwiskach autorów dodano zaś takie okre-

* Araceli Del Pozo Armentia, Professore di psicopedagogia all' Universidad Complutense de Madrid - España e di pedagogia all'Istituto Universitario Sophia - Italia. Indirizzo: Universidad Complutense de Madrid, C/ Rector Royo Villanova 1, Ciudad Universitaria 28040 Madrid. Mail: apa@ucm.es. 
ślenie: „Dwugłos zjednoczony”. Kim są owi autorzy? I tu kolejne zaskoczenie: żydówka, kobieta rabinka, i katolicki adwokat. „Zjednoczony dwugłos” to praca autorów wartościowych treści o formacji do dialogu i to nie tylko żydowsko-chrześcijańskiego, świadczą oni bowiem w swojej pracy o sztuce dialogu przeżywanego przez nich na szeroką skalę.

Dialog jest współcześnie szczególnie doceniany, bo któż nie odczuwał potrzeby czy pragnienia prawdziwego dialogu? A jednak, gdy patrzy się na bieg wydarzeń, konflikty i nieporozumienia, jakie zachodzą we współczesnym społeczeństwie, dialog może się wydawać utopią. Dlatego już samo mówienie o dialogu jest wyzwaniem. Ponadto „dialog dla życia”, jak jest to podkreślone w książce, zaprasza czytelnika do natychmiastowego jej otwarcia.

Autorzy mierzą się z wyzwaniami autentycznego dialogu międzyreligijnego i czynią to bardzo dynamicznie, wychodząc od życia, co więcej, od własnego życia i doświadczenia podążania na drodze szczerego, wspólnie przeżywanego dialogu, przynależąc do różnych religii, bardzo różnych światów i kontekstów. Z pedagogiczną czujnością otwierają przed nami drogi do dialogu żydów i chrześcijan, choć nie tylko pomiędzy nimi - do dialogu dogłębnie i prawdziwie szanującego tożsamości oraz różnice.

Książka jest jedyna w swoim rodzaju, ponieważ - jak pisze we Wstępie rabin Jack Bemporad - powstała jako owoc daru i wzajemnego poznawania się dwóch osób nadzwyczaj mądrych i wrażliwych, otwierających nowe drogi do poznawania się dwóch wspólnot, które ucząc się wzajemnie od siebie, mogą pracować razem w poszukiwaniu wspólnych fundamentów, aby zmierzyć się z aktualnymi problemami etycznymi i politycznymi.

Przytoczone niżej zdanie z książki daje wyobrażenie o jej aktualności: „Dialog rozwija się nie tylko poprzez dokumenty lub oświadczenia docenianych autorytetów. To też ma istotne znaczenie, lecz dialog nie jest czymś odtwarzanym czy narzucanym, ale wypływa i rodzi się z woli istot ludzkich, które z powodu oddzielenia decydują się budować mosty dla porozumienia" (s. 39).

Są w tej publikacji wyrażenia, które otwierają nowe horyzonty myślenia dziś bardzo potrzebnego: „dialog jest stylem życia i sposobem patrzenia na drugiego człowieka i na świat”; ,stosunek do drugiego”; ,zaufanie”; ,pozytywne spojrzenie”; ,uczciwość intelektualna i duchowa”. Jest i wiele innych koncepcji oraz refleksji, które budzą w czytelniku mnóstwo pytań.

Jako pedagog zwracam uwagę na przedstawione w książce specyficzne podejście do dialogu, precyzyjne na tyle, że można wręcz mówić o pewnej 
pedagogii dialogu. Autorzy piszą: „Nie jesteśmy pedagogami, lecz osobami nazywanymi «uczniami i krzewicielami dialogu», ponieważ podjęliśmy życiową decyzję, aby uczestniczyć w przygodzie spotkania z drugim" (s. 18).

Wart podkreślenia jest wyraźnie sprecyzowany cel tej książki, który autorzy określają jako: „tekst formacyjny” specyficzny dla dialogu, „narzędzie do dialogu":

Te strony zostały napisane z zamiarem podarowania narzędzi do zastosowania na całym świecie, aby przyczynić się do spotkania osób różnych religii i kultur. Są to narzędzia, które mogą być stosowane przede wszystkim przez tych, którzy w różnych wspólnotach zajmują się wychowaniem jako formatorzy, katecheci, nauczyciele, wychowawcy, lecz także w rodzinie, która jest uprzywilejowanym miejscem formowania ludzi do dialogu (s. 20).

Autorzy wyraźnie określi także odbiorców tej publikacji: „Ta książka została napisana z myślą o tych wszystkich, którzy w różnych obszarach podejmują zadania wychowania zarówno formalnie, jak i nieformalnie; we wspólnotach lub parafiach, w szkołach, w grupach młodzieży, w ruchach religijnych, grupach rekreacyjnych, kulturalnych czy uniwersyteckich" (s. 47).

Można zatem stwierdzić, że w tym kręgu mieszczą się wszyscy, ponieważ w gruncie rzeczy, w różnorodnych relacjach międzyosobowych, każdy nawet jeśli nie ma specyficznych zadań wychowawczych - musi mieć świadomość, że ponosi odpowiedzialność nieformalną, gdyż w pewnym sensie „wszyscy jesteśmy uczniami i nauczycielami”.

W publikacji jest mowa także o użyteczności dialogu. Autorzy precyzują - w sposób zdecydowany i podniosły - jaki jest ostateczny cel dojścia do niego: „Dialog nie ma celu utylitarnego, lecz transcendentny. Nie prowadzę go, bo będę miał taką czy inną korzyść, lecz sam fakt poświęcenia się temu nadaje godność mojemu istnieniu" (s. 165).

Interesujące jest też zdefiniowanie sztuki pytania i słuchania oraz zasad uczenia się zadawania pytań i słuchania odpowiedzi, co współcześnie jest mało popularne.

W końcowej części książki znajdujemy nie mniej interesujące, a wręcz bardzo istotne pogłębienie tego, co autorzy definiują jako ,przeszkody w dialogu" - otwiera to zupełnie nowy wymiar dialogu.

Nie jest łatwo zakończyć tę recenzję, gdyż jest jeszcze wiele wątków do zasygnalizowania, pozostawiam jednak Czytelnikom odkrywanie ich z na- 
dzieją, że udało mi się choć trochę wzbudzić zaciekawienie do podjęcia, wraz z autorami, przygody „dialogu życia”.

\author{
Araceli Del Pozo Armentia* \\ ORCID: 0000-0002-0088-5609 \\ Madryt, Hiszpania \\ Ttumaczenie: Stanistaw Grochmal, \\ Mariola Teresa Kozubek
}

* Araceli del Pozo Armentia, profesor psychopedagogiki na Universidad Complutense w Madrycie oraz pedagogiki w Instytucie Uniwersyteckim Sophia we Włoszech. Adres: Universidad Complutense de Madrid, C/ Rector Royo Villanova 1, Ciudad Universitaria 28040 Madrid; e-mail: apa@ucm.es. 